\title{
PERANCANGAN SISTEM INFORMASI PERSEDIAAN BARANG DAGANG DI PT DIMARCO MITRA UTAMA CABANG BANDUNG
}

\author{
${ }^{1}$ Tri Ramdhany, ${ }^{2}$ Deni Kurnia \\ 1,2Program Studi Sistem Informasi, STMIK LPKIA Bandung \\ ${ }^{1}$ tri@lpkia.ac.id,2Deni.fellow.lpkia.ac.id
}

\begin{abstract}
Abstrak-PT Dimarco Mitra Utama merupakan perusahaan yang bergerak di bidang distributor alat-alat rumah tangga yang diekspor dari berbagai negara di seluruh dunia. Saat ini bagian persediaan di PT Dimarco Mitra Utama Cabang Bandung, hanya bisa mengelola data persediaan barang dengan menggunakan manual. Setiap atktivitas keluar dan masuk barang dicatat ke kartu stok, sehingga saldo persediaan barang dagang pada setiap bulannya harus diinput kembali mengikuti saldo persediaan barang dagang bulan sebelumnya. Dalam aktivitas persediaan barang seperti ini besar kemungkinan bagian persediaan mengalami keterlambatan dalam melaporkan persediaan barang dagang, sering terjadinya kesalahan dalam pencatatan mutasi barang karena terdapat ribuan jenis barang dagang. Dengan melihat permasalahan yang ada saat ini, maka demi meningkatkan kinerja perusahaan. PT Dimarco Mitra Utama memerlukan sebuah aplikasi yang dapat mengatasi permasalahan pencatatan persediaan barang dagang dan dapat menghasilkan informasi persedian yang relevan. Oleh karena itu, untuk menangani permasalahan maka perlu dibangun suatu aplikasi berbasis komputer dengan metode perancangan terstruktur menggunakan tools DFD dan skema relasi serta menerapkan metode ROP dan EOQ untuk menjaga kontinuitas persediaan barang dagang.
\end{abstract}

Kata Kunci: Persediaan, Mutasi barang, Metode terstruktur, EOQ, ROP

\section{PENDAHULUAN}

Persediaan adalah suatu aktiva lancar yang meliputi barang-barang milik perusahaan dengan maksud dijual dalam periode usaha. Persediaan barang dagang (Marchadise inventory) adalah barang-barang yang dimiliki perusahaan untuk dijual kembali. Jika dilihat dari pengertiannya Persediaan merupakan faktor penting dalam sebuah perusahaan dagang, karena persediaan menentukan aktivitas operasi perusahaan. Persediaan merupakan bentuk investasi, keuntungan (laba) itu bisa diharapkan melalui penjualan pada kemudian hari. Oleh sebab itu, pada kebanyakan perusahaan, jumlah minimal persediaan harus dipertahankan untuk menjamin kontinuitas dan stabilitas penjualannya.

PT Dimarco Mitra Utama merupakan perusahaan yang bergerak di bidang distributor alat-alat rumah tangga yang diekspor dari berbagai negara di seluruh dunia. PT Dimarco Mitra Utama ini berdiri sejak tahun 1987 memiliki lima belas cabang yang tersebar di seluruh Indonesia. Kegiatan usaha perusahaan ini, yaitu menjalankan usaha penyediaan alat-alat rumah tangga seperti alat-alat memasak, kesehatan, dan kecantikan.

Saat ini, bagian persediaan di PT Dimarco Mitra Utama Cabang Bandung, hanya bisa mengelola data persediaan barang dengan menggunakan manual. Setiap atktivitas keluar dan masuk barang dicatat ke kartu stok, sehingga saldo persediaan barang dagang pada setiap bulannya harus di-input kembali mengikuti saldo persediaan barang dagang bulan sebelumnya. Dalam aktivitas persediaan barang seperti ini besar kemungkinan bagian persediaan mengalami keterlambatan dalam melaporkan persediaan barang dagang, sering terjadinya kesalahan dalam pencatatan mutasi barang karena terdapat ribuan jenis barang dagang. Dengan melihat permasalahan yang ada saat ini, maka PT Dimarco Mitra Utama memerlukan sebuah aplikasi yang dapat mengatasi permasalahan pencatatan persediaan barang dagang dan dapat menghasilkan informasi akuntansi persedian yang relevan.dari latar belakang masalah tersebut maka dapat diidentifikasi masalah sebagai berikut.

1. Sering terjadinya selisih saldo barang karena kesalahan pencatatan dalam proses mutasi barang dikartu stok.

2. Sering terjadinya kekurangan stok dan kelebihan stok digudang persediaan.

3. Terhambatnya pelaporan persediaan barang dagang, karena data dari kartu stok dipindahkan ke dalam format excel setiap bulannya yang membutuhkan ketelitian dan banyak waktu.

Dari identifikasi masalah yang ada dapat ditarik tujuan dari penelitian adalah sebagai berikut. Pada aplikasi ini dibuat form setiap transaksi mutasi barang masuk dan barang keluar untuk:

1. Setiap transaksi agar tidak terjadinya selisih saldo barang akibat salah peng-input-an;

2. Pada aplikasi ini dibuat warning stock dengan menggunakan model ROP (re-order point) dan EOQ (Economic order quantity) sehinnga dengan metode ROP dan EOQ ini menghindari kekurangan dan kelebihan persediaan yang dibutuhkan untuk kebutuhan operasional perusahaan;

3. Aplikasi ini menyajikan laporan saldo stock barang dan fasilitas mencetak laporan stok, sehingga mempercepat 
dalam proses pelaporan persediaan barang dagang setiap bulannya.

\section{METODE PENELITIAN}

A. Pendekatan Perancangan Sistem

Dalam perancangan sistem informasi persedian barang dagang di PT Dimmarco Bandung ini menerapkan pendekatan SADT (Structured Analysis And Design Technique) SADT sebagai metodologi pengembangan sistem terstruktur juga menganut konsep dekomposisi, yaitu menggambarkan terlebih dahulu sistem secara utuh (whole system) sebagai tingkat tertinggi (Top Level) dan memecahnya lebih rinci. Untuk lebih jelas dapat dilihat pada gambar berikut ini.

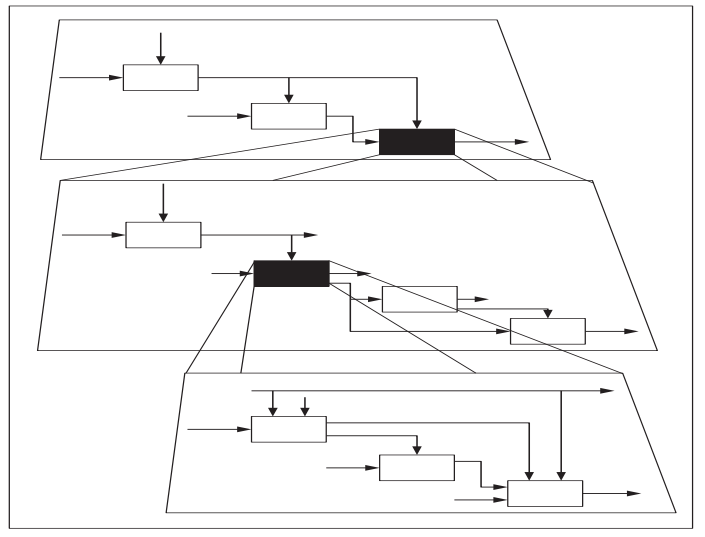

Gambar 1 Dekomposisi SADT

B. Teknik Pengumpulan Data

Teknik pengumpulan data yang digunakan dalam penelitian ini adalah sebagai berikut.

1. Penelitian Kepustakaan (Library Search)

Teknik kepustakaan merupakan suatu teknik pengumpulan data secara teoretis dengan cara membaca, membahas, serta mempelajari berbagai macam buku dan simber bacaan lainnya sebagai penunjang teori terkait dengan masalah yang akan diteliti.

2. Penelitian Lapangan (Field Reserach)

Penelitian lapangan merupakan suatu teknik pengumpulan data yang dilakukan dengan cara melakukan penelitian secara langsung pada perusahaan untuk mendapatkan data dan informasi yang diperlukan dalam menyelesaikan penelitian ini.

Untuk mendapatkan data dan informasi yang diperlukan dari perusahaan yang diteliti

\section{HASIL DAN PEMBAHASAN}

A. Prosedur Sistem Berjalan

Adapun prosedur dari sistem yang sedang berjalan di PT

Dimarco Mitra Utama Cabang Bandung adalah sebagai berikut.

1. Prosedur Penerimaan Barang

a. Angkutan (ekspedisi) menyerahkan Surat Jalan (lembar ke-2) dan Bukti Pemindahan stok (lembar ke-2) beserta barang ke bagian gudang. b. Bagian administrasi inventory memeriksa kecocokan dokumen dengan fisik barang.

c. Jika sudah sesuai, Bagian Administrasi Inventory mentandatangani pada Bukti Pemindahan Stok, yang selanjutnya Bukti Pemindahan Stok di-copy dan diserahkan ke gudang asal barang, sebagai tanda bahwa barang sudah diterima.

d. Jika tidak sesuai antara Bukti Pemindahan Stok dengan fisik barang, maka Bagian Administrasi Inventory memberikan catatan apa saja yang perlu dicantumkan pada kolom yang tersedia di Bukti Pemindahan Stok, yang kemudian ditandatangani lalu di copy dan copy-an

e. Diserahkan ke gudang asal barang, sebagai tanda bahwa barang sudah diterima.

f. Kemudian Bagian Administrasi Inventory mencatat data barang sesuai Bukti Pemindahan Stok ke buku stok sebagai penerimaan barang.

g. Bagian Administrasi Inventory mengarsipkan Bukti Pemindahan Stok dan Surat Jalan yang diterima.

h. Bagian Administrasi Inventory menyimpan barang ke gudang.

2. Pengelolaan Barang (Stok Opname)

a. Bagian Administrasi Inventory melakukan Stok Opname dengan melihat data dari kartu stok.

b. Setelah melakukan pemeriksaan kartu stok dengan saldo fisik barang, Bagian Administrasi Inventory membuat Laporan Persediaan Akhir pada setiap akhir bulan sebanyak dua rangkap, yang kemudian LP 1 di arsipkan Bagian Administrasi Inventory dan LP 2 di serahkan kepada Kepala ADM.

3. Prosedur Pengeluaran Barang

a. Bagian Administrasi Inventory menerima SPB (Surat Permintaan Barang) dari Salesman.

b. Bagian Administrasi Inventory cek ketersediaan barang di gudang.

c. Jika tersedia Bagian Administrasi Inventory membuat Surat Jalan rangkap tiga dan mengeluarkan barang dari gudang.

d. Bagian Administrasi Inventory menyerahkan Surat Jalan dan barang kepada salesman.

e. Bagian Administrasi Inventory mencatat pengurangan stok di kartu stok dilihat dari surat jalan yang sudah ditandatangani salesman.

f. Jika permintaan barang tidak tersedia, maka Bagian Administrasi Inventory membuat Surat Order Barang (SOB) sebagai permintaan barang ke Gudang Pusat.

g. Surat Jalan yang sudah ditandatangani diarsipkan

1. Lembar ke-1 diarsipkan Bagian Gudang.

2. Lembar ke-2 diarsipkan Kepala Administrasi.

3. Lembar ke-3 diserahkan kepada salesman.

Untuk memperjelas dari sistem yang berjalan diperusahaan maka akan digambarkan menggunakan DFD tanpa batas otomatisasi dengan tujuan gambaran DFD sistem berjalan dapat dibandingkan dengan sistem usulan yang akan dikembangkan sehingga dapat terlihat perubahan dan perbaikan sistem yang dilakukan. Gambar 2 dan Gambar 3 menunjukkan DFD sistem berjalan. 


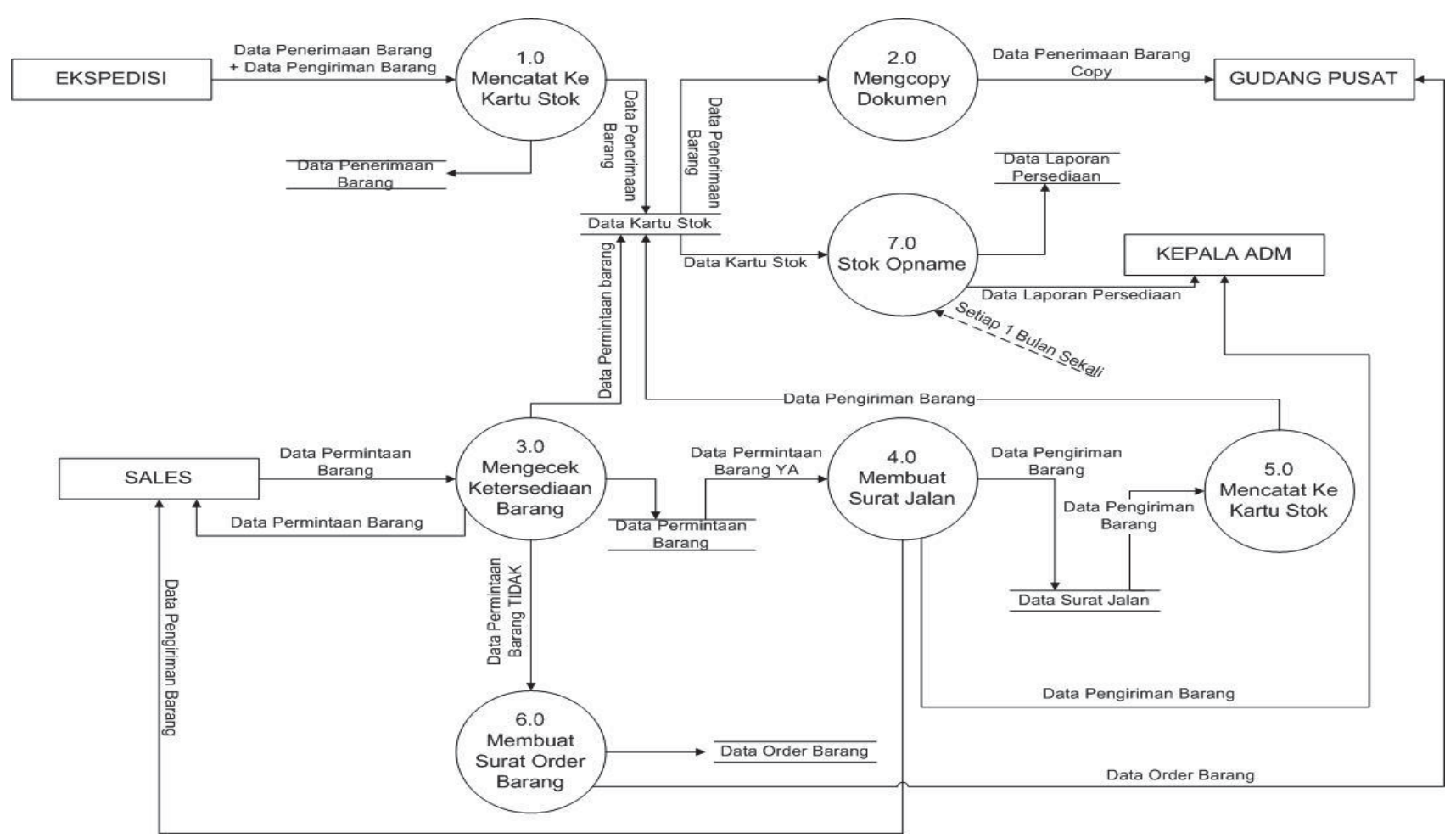

Gambar 2 DFD Level 0 Sistem Berjalan

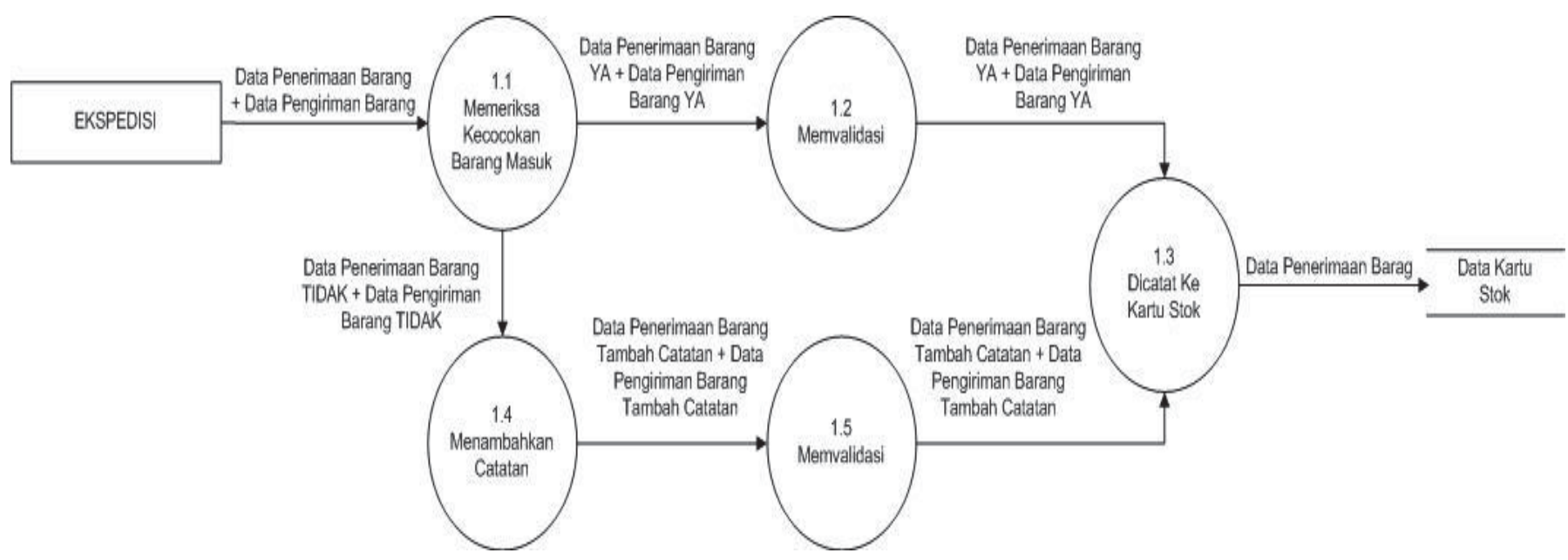

Gambar 3 DFD Level 1 Proses 1 Mencetak Kartu Stock

B. Gagasan Sistem Usulan

Dari sistem berjalan yang sudah digambarkan sebelumnya, kemudian menentukan gagasan yang diusulkan dalam menyelesaikan permsalahan sebagai berikut.

1. Mengkomputerisasi beberapa proses yang ada dalam sistem berjalan sebagai berikut.

a. Proses 1.0 menginput barang masuk.

b. Proses 4.0 membuat surat order barang.

c. Proses 5.0 membuat surat jalan.

d. Proses 6.0 membuat laporan persediaan.

e. Proses 7.0 stock opname.
2. Menambah proses baru, yaitu menghitung ROP dan EOQ yang di masukan dalam proses 4.0 membuat surat order barang.

3. Menambahkan Dialog Warning untuk menampilkan datadata barang yang sudah mendekati nilai ROP dan segera harus dipesan sebanyak EOQ.

Berikut ini rancangan gagasan dari sistem usulan menggunakan DFD sistem usulan dengan batas otomatisasi. 


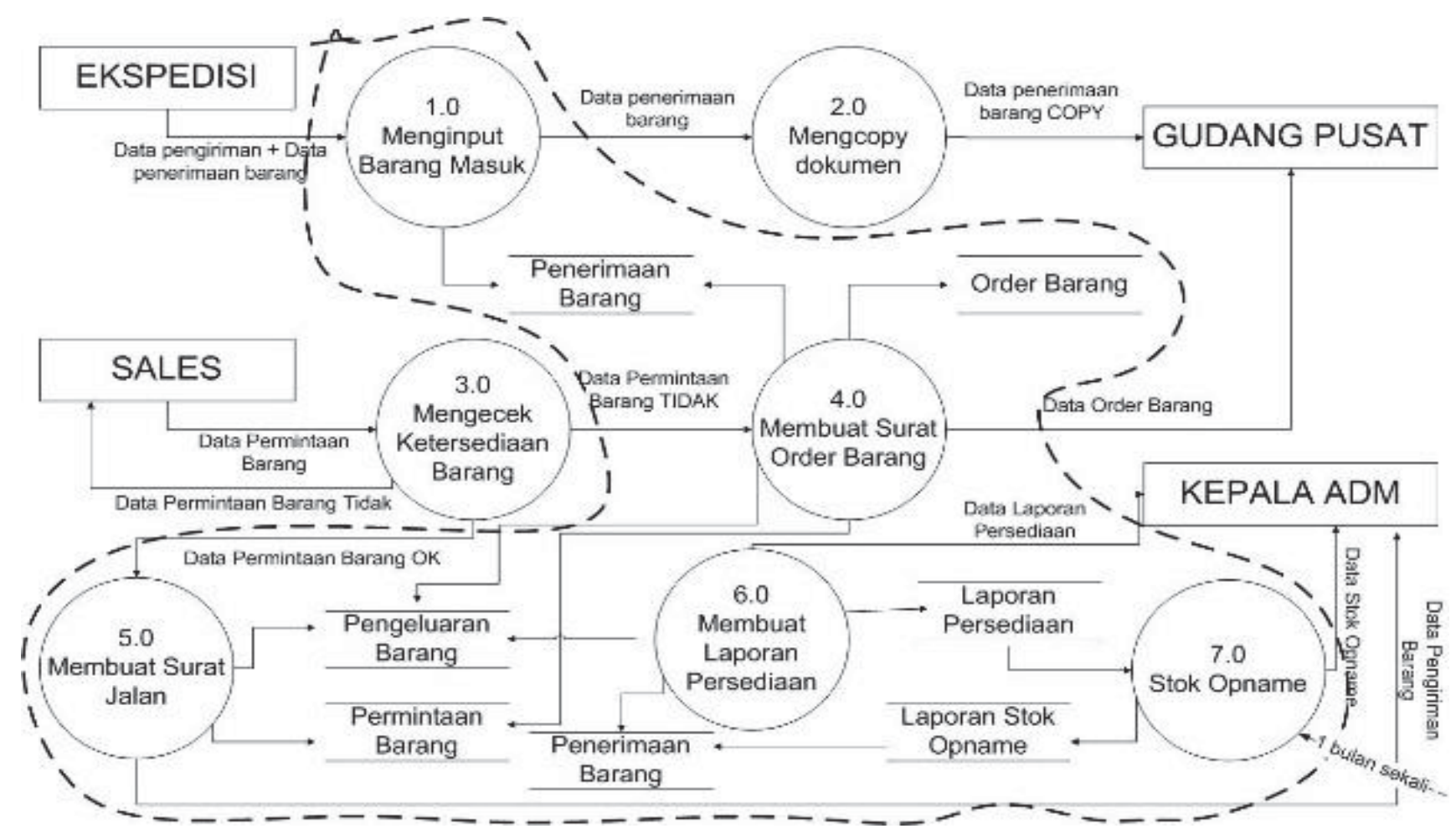

Gambar 4 DFD Level 0 dengan Batas Otomatisasi

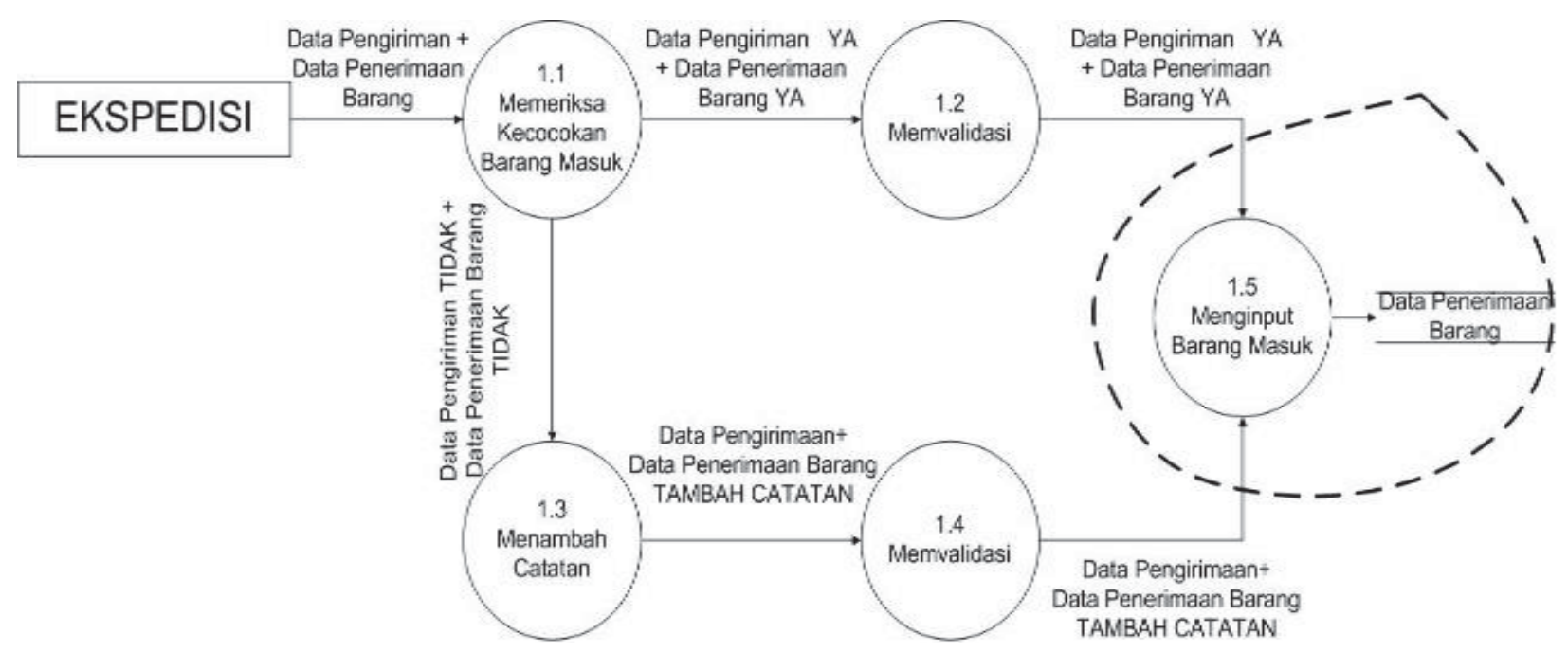

Gambar 5 DFD Level 1 Proses 1.0 Meng-input Barang Masuk dengan Batas Otomatisasi 


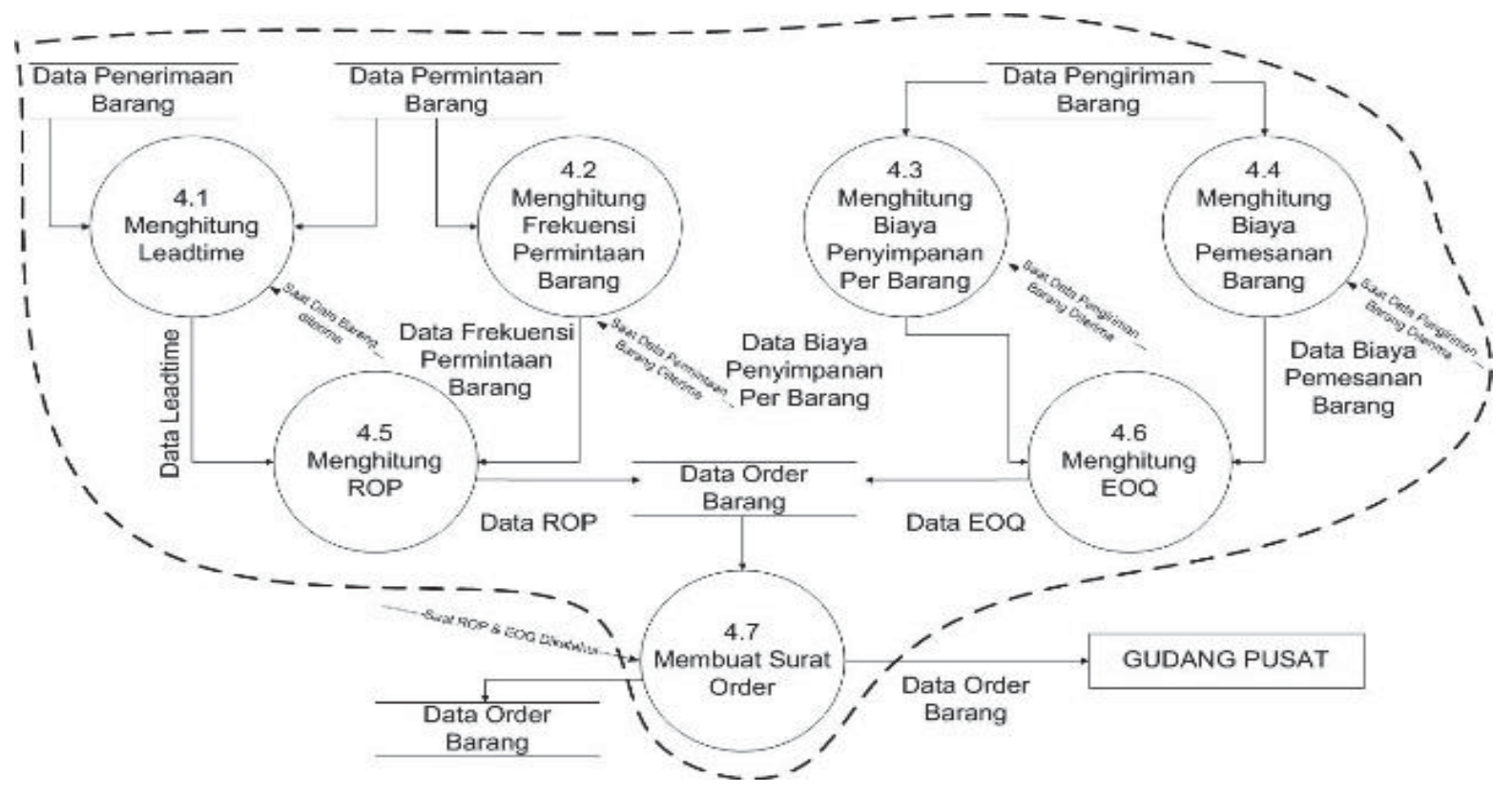

Gambar 6 DFD Level 1 Proses 4.0 Membuat Surat Order Barang dengan Batas Otomatisasi

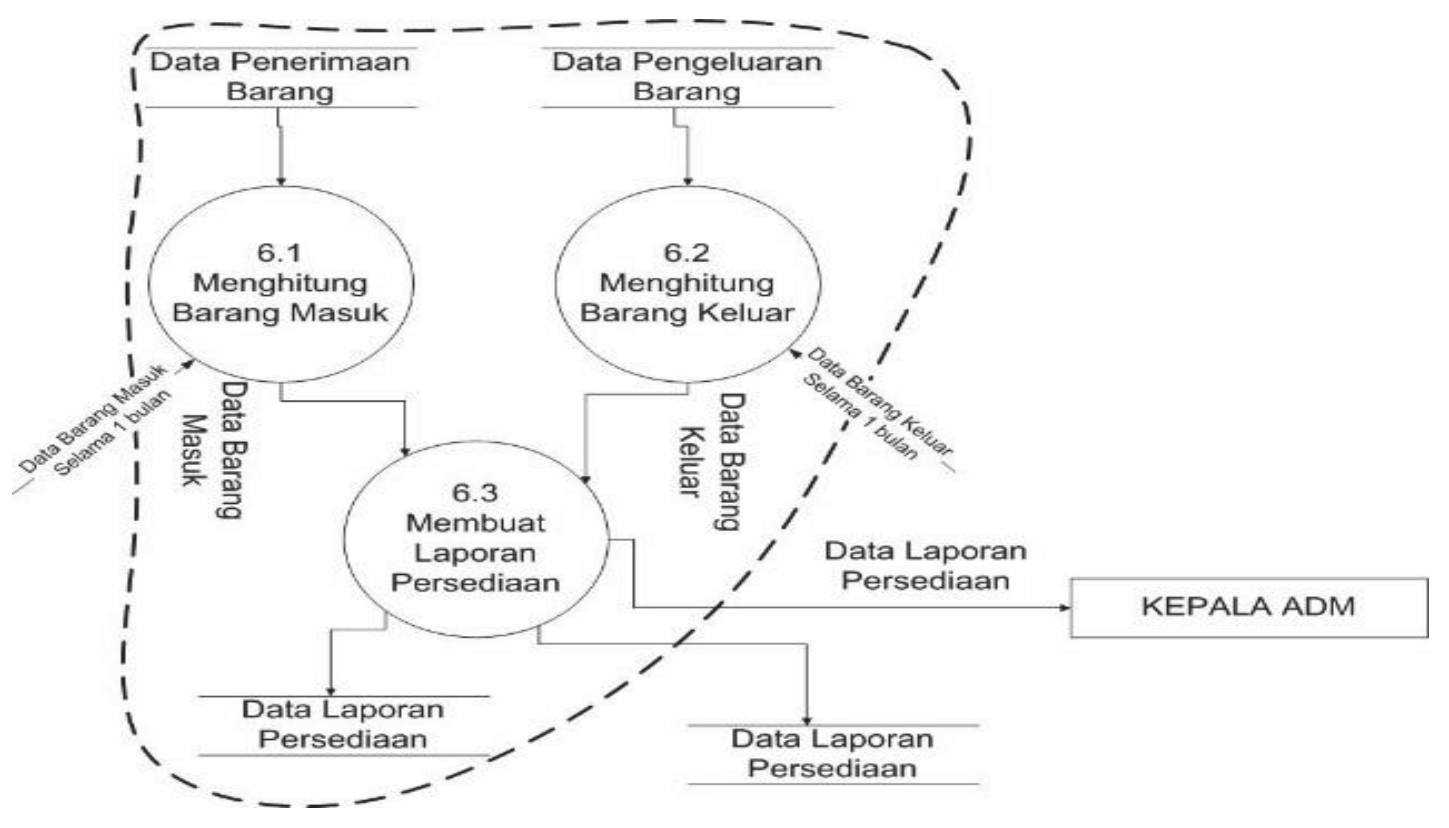

Gambar 7 DFD Level 1 Proses 6.0 Membuat Laporan Persedian dengan Batas Otomatisasi

C. Kamus Data Sistem Usulan

Sebelum merancang database untuk kebutuhan sistem usulan maka perlu terlebih dahulu mendskripsikan data flow dan data store ke dalam kamus data sehingga dapat diperoleh deskripsi dari data yang mengalir dan dapat terdefinisi juga struktur data dari aliran dan data store yang ada di dalam DFD.
Kemudian dari kamus data yang telah dibuat kemudian dirancang database yang dibutuhkan dalam melayani ketersedian data di sistem informasi persediaan yang sedang dikembangkan. Untuk lebih jelasnya gamabran dari kamus data yang dibutuhkan dapat dilihat pada Tabel I - Tabel VI berikut ini: 
TABEL I

KAMUS DATA DAFTAR BARANG

\begin{tabular}{|c|c|}
\hline Nama & Data Barang, Daftar Barang \\
\hline Deskripsi & $\begin{array}{l}\text { Informasi mengenai data barang yang } \\
\text { dikelola oleh pengelola barang. }\end{array}$ \\
\hline Struktur Data & $\begin{array}{l}\text { [KodeBarang }]+[\text { NamaBarang }]+\text { Satuan } \\
+[\text { Saldo Awal }]+[\text { Saldo Akhir }]\end{array}$ \\
\hline [Kode Barang] & $\{\mathrm{A}-\mathrm{Z}\}\{0-9\}$ \\
\hline [Nama Barang] & $\{\{\mathrm{A}-\mathrm{Z}\}\{\mathrm{a}-\mathrm{z}\}\{0-9\}\}$ \\
\hline Satuan & $\{\{\mathrm{A}-\mathrm{Z}\}\{\mathrm{a}-\mathrm{z}\}\{0-9\}\}$ \\
\hline [Stock Awal] & $\{0-9\}$ \\
\hline [Stock Akhir] & $\{0-9\}$ \\
\hline Harga & $\{0-9\}$ \\
\hline [Par Stock] & $\{0-9\}$ \\
\hline $\mathrm{ROP}$ & $\{0-9\}$ \\
\hline EOQ & $\{0-9\}$ \\
\hline [Biaya Pesan] & $\{0-9\}$ \\
\hline
\end{tabular}

TABEL II

KAMUS DATA PENERIMAAN BARANG (BUKTI PEMINDAHAN STOCK)

\begin{tabular}{|l|l|}
\hline Nama & Bukti Pemindahan Stok \\
\hline Deskripsi & $\begin{array}{l}\text { Informasi mengenai daftar barang yang } \\
\text { dikirim oleh gudang pengirim, atau } \\
\text { sebagai bukti penerimaan barang masuk } \\
\text { ke gudang penerima. }\end{array}$ \\
\hline Struktur Data & $\begin{array}{l}\text { No BPS+Tanggal+Asal Gudang+ } \\
\{\text { No_BPS}+ \text { Kode Barang+Nama } \\
\text { Barang+Qty Masuk+Keterangan }\}\end{array}$ \\
\hline [No. BPS $]$ & $\{$ A-Z $\}\{0-9\}\}$ \\
\hline Tanggal & $\{$ A-Z $\}\{\mathrm{a}-\mathrm{Z}\}\{0-9\}\}$ \\
\hline$[$ Asal Gudang $]$ & $\{$ A-Z $\}\{\mathrm{a}-\mathrm{Z}\}\}$ \\
\hline$[$ Kode Barang] & $\{0-9\}$ \\
\hline$[$ Nama Barang $]$ & $\{\{\mathrm{A}-\mathrm{Z}\}\{\mathrm{a}-\mathrm{Z}\}\}$ \\
\hline$[$ Qty Masuk $]$ & $\{0-9\}$ \\
\hline Keterangan & $\{\{\mathrm{A}-\mathrm{Z}\}\{\mathrm{a}-\mathrm{Z}\}\}$ \\
\hline
\end{tabular}

TABEL III

KAMUS DATA BUKTI PENGELUARAN BARANG (SURAT JALAN)

\begin{tabular}{|c|c|}
\hline Nama & Surat Jalan \\
\hline Deskripsi & $\begin{array}{l}\text { Informasi mengenai nama-nama } \\
\text { barang yang dikirim dan tujuan } \\
\text { penerima barang. }\end{array}$ \\
\hline Struktur Data & $\begin{array}{l}\text { No_SJ+Tanggal+No Sales+Nama } \\
\text { Sales+Id Petugas }+ \\
\text { NamaPetugas+Tujuan }+\{\text { No SJ }+\underline{\text { Kod }} \\
\text { Barang+Nama Barang }+ \text { QtyKeluar }\}\end{array}$ \\
\hline No_SJ & $\{\{A-Z\}\{0-9\}\}$ \\
\hline Tanggal & $\{\{\mathrm{A}-\mathrm{Z}\}\{\mathrm{a}-\mathrm{z}\}\{0-9\}\}$ \\
\hline [No Sales] & $\{0-9\}$ \\
\hline [Nama Sales] & $\{\{\mathrm{A}-\mathrm{Z}\}\{\mathrm{a}-\mathrm{Z}\}\}$ \\
\hline [Id Petugas] & $\{0-9\}$ \\
\hline [Nama Petugas] & $\{\{\mathrm{A}-\mathrm{Z}\}\{\mathrm{a}-\mathrm{Z}\}\}$ \\
\hline Tujuan & $\{\{\mathrm{A}-\mathrm{Z}\}\{\mathrm{a}-\mathrm{z}\}\}$ \\
\hline [Nama Barang] & $\{\{\mathrm{A}-\mathrm{Z}\}\{\mathrm{a}-\mathrm{z}\}\{0-9\}\}$ \\
\hline [Qty Keluar] & $\{0-9\}$ \\
\hline
\end{tabular}

TABEL IV

KAMUS DATA SURAT ORDER

\begin{tabular}{|l|l|}
\hline Nama & Surat Order \\
\hline Deskripsi & $\begin{array}{l}\text { Informasi nama barang barang yang } \\
\text { diminta bagian Persediaan ke Gudang } \\
\text { Pusat }\end{array}$ \\
\hline Struktur & $\begin{array}{l}\text { No Surat Order+Tanggal+ }+ \text { No Surat } \\
\underline{\text { Order+ }}\end{array}$ \\
\hline $\begin{array}{l}\text { Kode Barang+Nama Barang +Qty } \\
\text { Order+ } \\
\text { Keterangan }\}\end{array}$ \\
\hline No Surat Order $]$ & $\{0-9\}$ \\
\hline Tanggal & $\{$ A-Z $\}\{\mathrm{a}-\mathrm{Z}\}\{0-9\}\}$ \\
\hline$[$ Kode Barang] & $\{\{\mathrm{A}-\mathrm{Z}\}\{0-9\}\}$ \\
\hline Nama Barang & $\{\{\mathrm{A}-\mathrm{Z}\}\{\mathrm{a}-\mathrm{Z}\}\{0-9\}\}$ \\
\hline Qty Order & $\{0-9\}$ \\
\hline Keterangan & $\{\{\mathrm{A}-\mathrm{Z}\}\{\mathrm{a}-\mathrm{Z}\}\{0-9\}\}$ \\
\hline
\end{tabular}

TABEL V

KAMUS DATA STOCK OPNAME

\begin{tabular}{|l|l|}
\hline Nama & Stok Opname \\
\hline Deskripsi & $\begin{array}{l}\text { Informasi jumlah saldo barang yang } \\
\text { sudah diperiksa kesesuaiannya dengan } \\
\text { saldo fisik barang yang dilakukan oleh } \\
\text { Bagian Persediaan dengan Kepala } \\
\text { Administrasi }\end{array}$ \\
\hline Struktur & $\begin{array}{l}\text { No SO+Tanggal+Id Petugas+Nama } \\
\text { Petugas+Yang } \\
\text { Memeriksa+Menetahui+ }+\underline{\text { No SO }}+\underline{\text { Kode }} \\
\text { Barang+ }\end{array}$ \\
\hline Nama Barang+Saldo \\
Akhir+Fisik+Keterangan $\}$
\end{tabular}

TABEL VI

KAMUS DATA CATATAN PERSEDIAAN

\begin{tabular}{|l|l|}
\hline Nama & Laporan Persediaan \\
\hline Deskripsi & $\begin{array}{l}\text { Informasi stok awal, mutasi, dan stok } \\
\text { akhir persediaan barang dagang. }\end{array}$ \\
\hline Struktur & $\begin{array}{l}\text { Nama Barang+Jenis Barang+ } \\
\text { Tanggal+No Bukti+Keterangan+ } \\
\text { Saldo Awal+Mutasi Masuk+Mutasi } \\
\text { Keluar+Saldo Akhir }\}+ \text { Jumlah }\end{array}$ \\
\hline Nama Barang & $\{\{$ A-Z $\}\{$ a-z $\}\{0-9\}\}$ \\
\hline Jenis Barang & $\{\{$ A-Z $\}\{\mathrm{a}-\mathrm{Z}\}\{0-9\}\}$ \\
\hline Tanggal & $\{\{\mathrm{A}-\mathrm{Z}\}\{\mathrm{a}-\mathrm{Z}\}\{0-9\}\}$ \\
\hline No_Bukti & $\{\{\mathrm{A}-\mathrm{Z}\}\{0-9\}\}$ \\
\hline Keterangan & $\{\{\mathrm{A}-\mathrm{Z}\}\{\mathrm{a}-\mathrm{Z}\}\{0-9\}\}$ \\
\hline Saldo Awal & $\{0-9\}$ \\
\hline Mutasi Masuk & $\{0-9\}$ \\
\hline Mutasi Keluar & $\{0-9\}$ \\
\hline Saldo Akhir & $\{0-9\}$ \\
\hline Jumlah & $\{0-9\}$ \\
\hline Yang Membuat & $\{\{\mathrm{A}-\mathrm{Z}\}\{\mathrm{a}-\mathrm{Z}\}\}$ \\
\hline
\end{tabular}




\section{Rancangan Database}

Setelah melakukan rancangan proses dan alur data menggunakan data flow diagram, maka tahap berikutnya adalah menentukan rancangan database dari sistem informasi yang akan di bangun, yaitu sistem informasi persedian barang dagang (Gambar 8).

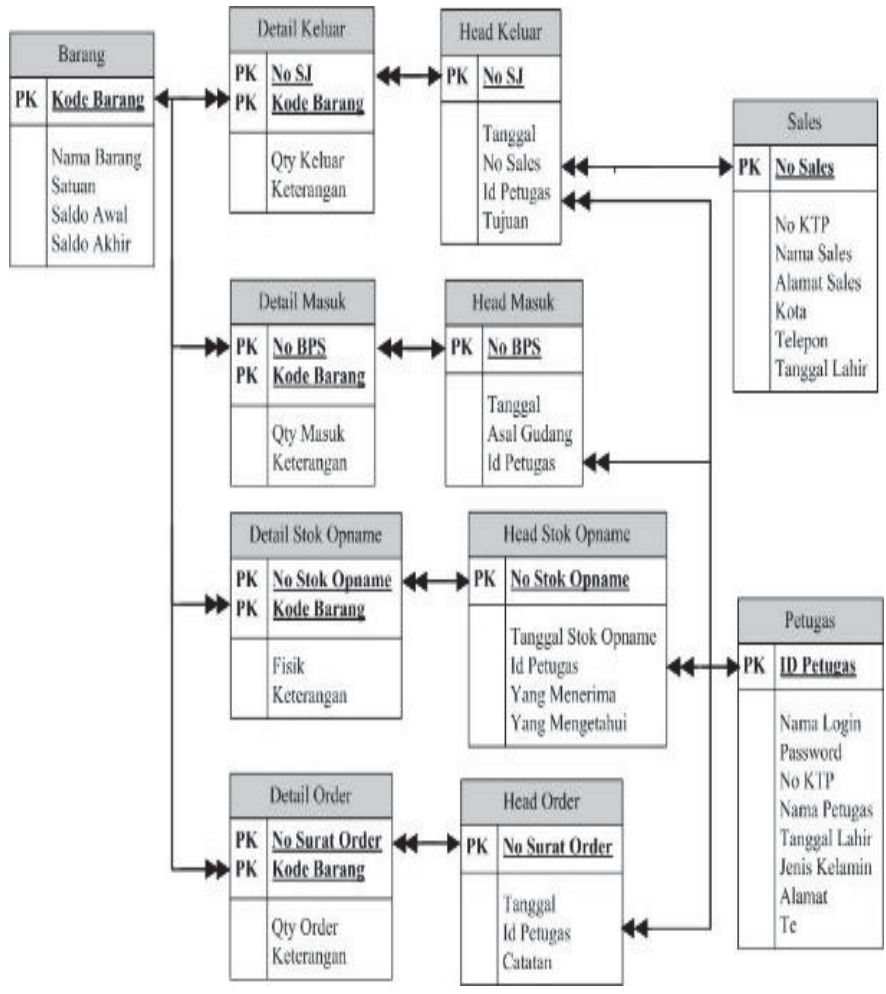

Gambar 8 Skema Relasi Sistem Infromasi Usulan

\section{E. Referensi}

Pengertian Sistem Informasi Akuntansi menurut Krismiaji dalam bukunya yang berjudul "Sistem Informasi Akuntansi" menyatakan bahwa "Sistem Informasi Akuntansi adalah sebuah sistem yang memproses data dan transaksi guna menghasilkan informasi yang bermanfaat untuk merencanakan, mengendalikan dan mengoperasikan bisnis" [1]. Adapun pengertian persediaan menurut Rudianto dalam bukunya yang berjudul "Akuntansi Koperasi" menyatakan bahwa: "Persediaan adalah sejumlah barang jadi, bahan baku, barang dalam proses yang dimiliki koperasi dengan tujuan untuk dijual atau diproses lebih lanjut" [2]. Menurut Mulyadi menjelaskan bahwa persedian pun dibagi menjadi beberapa jenis, yaitu persedian produk jadi, persedian barang dalam proses, persedian bahan baku, persedian bahan penolong, persedian bahan habis pabrik, persediaan suku cadang [3].

Dalam sistem informasi persedian ada hal penting yang perlu diperhatikan, yaitu bagaimana kontinuitas persedian dapat berjalan dengan baik oleh karena itu diambil metode yang dapat menghitung kebutuhan persediaan secara ideal dan menghitung waktu yang paling ideal dalam melakukan pemesanan kembali, berikut ini metode yang digunakan. Economic Order Quantity (EOQ) Menurut Indriyo Gitosudarmo dan Basri dalam bukunya "Manajemen
Keuangan", "EOQ adalah sebagai volume atas jumlah pembelian yang paling ekonomis untuk dilaksanakan pada setiap kali pembelian"'[4].

Masih dalam bukunya Indriyo Gitosudarmo dan Basri mendefinisikan besarnya EOQ dengan rumus:

$$
E O Q=\sqrt{\frac{2 \times B \times O}{C}}
$$

Dimana:

$\mathrm{B}=$ Jumlah barang yang dipesan dalam periode waktu tertentu $\mathrm{O}=$ Biaya pesanan untuk setiap kali permintaan (ongkos * pesan)

$\mathrm{C}=$ Biaya penyimpanan per barang $(0.25 *$ harga satuan per barang).

Pengertian Reorder point (ROP) menurut Indriyo Gitosudarmo dan Basri dalam bukunya "Manajemen Keuangan", "ROP adalah saat waktu tertentu perusahaan harus mengadakan pemesanan bahan dasar kembali, sehingga datangnya pesanan tersebut tepat dengan habisnya bahan dasar yang dibeli khususnya dengan metode EOQ"[4].

Masih dalam bukunya Indriyo Gitosudarmo dan Basri mengemukakan beberapa cara untuk menetapkan besarnya ROP, yaitu:

1. menggunakan jumlah penggunaan selama leadtime (waktu datangnya bahan dasar dari pemesanan datang) ditambah presentasi tertentu sebagai persediaan bersih (safety stock);

2. menetapkan jumlah penggunaan selama leadtime ditambah penggunaan selama periode tertentu safety stock;

3. penetapan leadtime dengan biaya minimum;

Sedangkan untuk menghitung ROP dapat menggunakan rumus sebagai berikut:

$R O P=$ leadtime x kebutuhan barang/satuan waktu

Dimana leadtime adalah waktu yang dihitung dari tanggal pemesanan sampai tanggal barang diterima.

Dalam melakukan analisis sistem informasi diperlukan satu pendekatan agar hasil analisis dan rancangan dapat diukur apakah berhasil atau tidak. Perancangan yang dilakukan menggunakan pendekatan terstruktur, pendekatan terstruktur ini dilengkapi dengan tools yang dibutuhkan dalam pengembangan sistem sehingga didapatkan hasil akhir sebuah sistem yang strukturnya didefinisikan dengan baik dan jelas.

Tools yang digunakan dalam perancangan sistem informasi ini menggunakan DFD. Menurut Krismiaji "DFD secara grafis menjelaskan arus data dalam sebuah organisasi. Teknik ini digunakan untuk mendokumentasikan sistem yang digunakan sekarang dan untuk merencanakan serta mendesain sistem yang baru" [1].

Tools berikutnya yang digunakan adalah kamus data. Kamus data menurut Andi Kristanto adalah "kumpulan 
elemen-elemen atau simbol-simbol yang digunakan untuk membantu dalam penggambaran atau pengidentifikasian setiap field atau file di dalam sistem" [5]. Akan tetapi, untuk menggambarkan kebutuhan peyimpanan data dari sistem informasi yang telah diusulkan tentu perlu dibuat skema relasi antar tabel untuk kebutuhan DBMS pada sistem informasi yang diusulkan. DBMS dapat diartikan "suatu program komputer yang digunakan untuk memasukkan, mengubah, menghapus, memanipulasi, dan memperoleh data/informasi dengan praktis dan efisien" [6].

\section{KESIIMPULAN}

Transaksi persediaan akan dapat berjalan lancar sesuai dengan keperluan atau kebutuhan pemakai, oleh karena itu dari hasil perancangan yang telah dilakukan dapat diambil kesimpulan sebagai berikut.

1. Dengan adanya aplikasi yang telah dirancang diharapkan akan memudahkan pengguna dalam melakukan pengelolaan mutase barang masuk dan barang keluar. Sehingga penyajian laporan persedian dapat dilakukan lebih cepat.

2. Dengan Adanya rancangan dialog warning sistem stok barang fasilitas ini memungkinkan untuk mengontrol kuntinuitas barang yang tersedia di gudang maka dengan adanya fasilitas ini dapat ditekan semaksimal mungkin kemungkinan terjadinya Stock out (kekurangan stok) atapun Over stock (kelebihan stok)

\section{DAFTAR PUSTAKA}

[1] Krismiaji. Sistem Informasi Akuntansi. Edisi 3. Yogyakarta: UPP STIM YKPN. 2010.4

[2] Rudianto. Akuntansi Koperasi. Edisi Kedua. Jakarta: Erlangga. 2010.6

[3] Mulyadi. Sistem Akuntansi. Jakarta: Salemba Empat. 2001.5

[4] Gitosudarmo Indriyo dan Basri. Manajemen Keuangan. Yogyakarta: BPFE-UGM. 2008.1

[5] Kristanto Andi. Perancangan Sistem Informasi dan Aplikasi.Yogyakarta: Gava media. 2008.3

[6] Kadir Abdul. Konsep dan Tuntunan Praktis Basis Data.Yogyakarta: Andi Offset. 2003.2 